
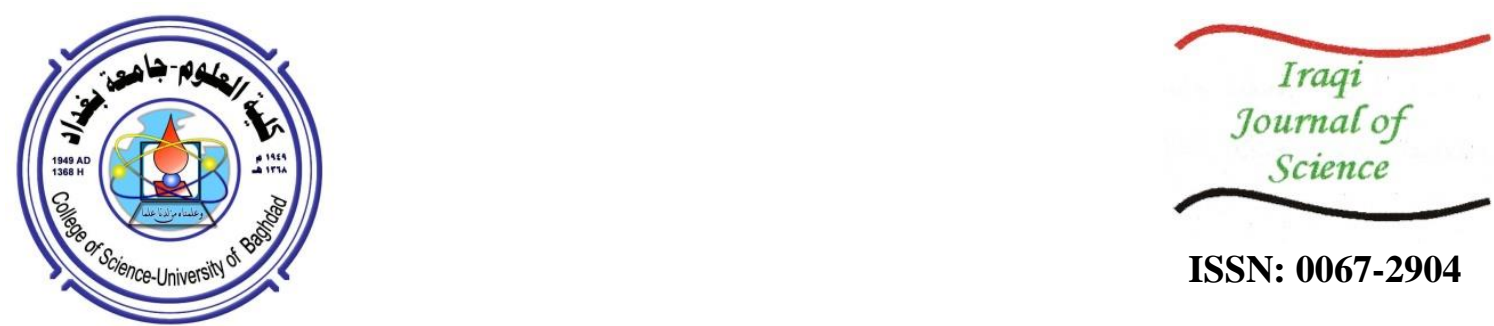

ISSN: 0067-2904

\title{
Virulence Potential of Penicillium Chrysogenum Isolated from Subclinical Bovine Mastitis
}

\author{
Fadwa Abdul Razaq Jameel*, Shaimaa Nabhan Yassein \\ Department of Microbiology, college of Veterinary Medicine, University of Baghdad, Baghdad, Iraq
}

Received: $28 / 7 / 2020$

Accepted: $9 / 10 / 2020$

\begin{abstract}
The present study aimed to the isolation and identification of Penicillium chrysogenum from subclinical bovine mastitis as well as the evaluation of their potential to produce the main virulence factors by assessing proteinase production, urease production, growth rate at $37^{\circ} \mathrm{C}$, and hemolytic activity on Blood agar. One hundred milk samples were assembled from the White Gold village and surrounded outlying farms of Abu-Ghraib, Baghdad province, during the period from November 2018 to March 2019. Each milk sample was tested for California Mastitis (CMT). The results indicated that $85 \%$ of the samples gave positive (+ve) results for CMT. Sixty six mycotic isolates were detected, including 31 isolates of Penicillium spp. (46.9\%) and 23 isolates of $P$. chrysogenum (34.8\%). All of P. chrysogenum isolates were identified by culturing on Sabouraud Dextrose Agar and Czapek Doxes Agar at $25^{\circ} \mathrm{C}$ for 5-7 days. $P$. chrysogenum was diagnosed by polymerase chain reaction (PCR) based on the internal transcribed spacer (ITS) region of fungal ribosomal DNA (rDNA). The results of genetic identities showed that this fungus had $94 \%$ matching with the reference strain. Also, this study indicated that $P$. chrysogenum has several virulence factors with the ability of this fungus to degrade both proteins (albumin and casein), hydrolyse urea, and grow ate $37^{\circ} \mathrm{C}$, but not to confer hemolytic activity on Blood Agar.
\end{abstract}

Keywords: Penicillium chrysogenum, bovine mastitis, PCR, virulence factors, proteinase production, urease production.

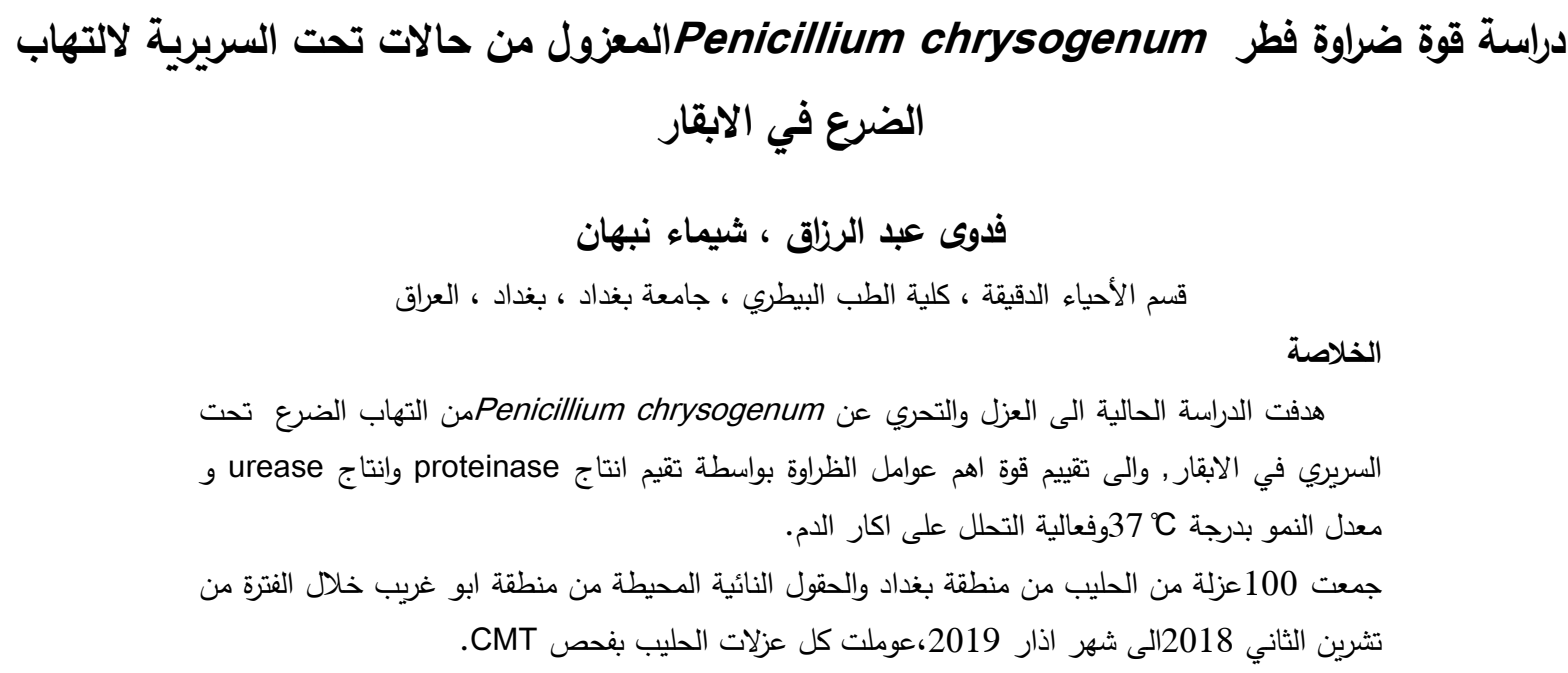

*Email: fadwajamee891@gmail.com 


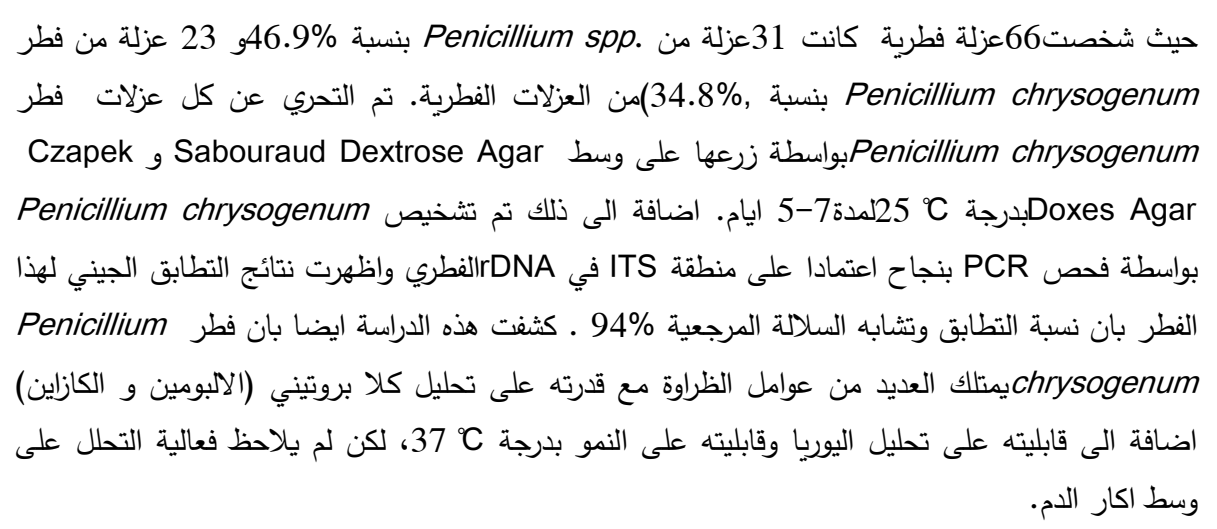

\section{Introduction}

Mastitis is one of the principal pathologies in the dairy bovine oppression. The majority of cases are caused by bacteria [1], but there are also cases caused by fungi [2]. Mycotic mastitis has become an increasing problem in animals and humans due to the wide use of antibiotics in mastitis therapy $[3,4]$. A previous study [5] isolated several types of fungi from mammary secretions of lactating cows and buffaloes, including Penicillium spp. , especially Penicillium chrysogenum.

Penicillium chrysogenum is a filamentous fungus [6] which belongs to the family Trichocomaceae [7], genus Penicillium, and characterized by the typical brush-shaped morphology of its conidiophores [8]. The reproduction of this fungus is only asexual and due to the economic importance of this fungus which lead to revolution of sexual stage [9].It is found in soil, wood, and decaying vegetation, and because of its dry, one-celled conidia, it is airborne [10]. Also, it is usually found in indoor environments and associated with food spoilage. It is known as an industrial producer of b-lactam antibiotics, particularly penicillin. The current production strains result from several decades of classical strain improvement (CSI) [11].

Polymerase chain reaction (PCR) is a rapid diagnostic technique that can be used for the detection of numerous fungal species with good pretest and posttest probabilities [12]. In fungi, PCR depends on the internal transcribed spacer (ITS) regions of fungal ribosomal DNA (r DNA) for the identification of many fungi, including $P$. chrysogenum [13]. This ITS region in fungi consists of 3 sub-regions, namely ITS1 and ITS2, which are considered as variable regions, and 5.8S gene, which is considered as the highly conserved region [14].

Virulence factors are products or a property of fungus that increases its ability to attack the host [15]. P. chrysogenum has the potential to produce many of virulence factors like proteases which are degradative enzymes $[16,17]$. Other properties of this fungus include growth at $37^{\circ} \mathrm{C}[18]$, hemolytic activity [19], and production of urease [15].

Very little is known about isolation and detection of virulence factors of $P$. chrysogenum. The objectives of this study are to give a special attention for the isolation and identification of $P$. chrysogenum besides studying the potential of virulence factors of this fungus isolated from subclinical bovine mastitis.

\section{Materials and methods \\ Collection of milk samples}

One hundred, four quarter, milk samples were collected from seemingly healthy cows from different areas in Baghdad region and the surrounded outlying farms of Abu-Ghraib during November 2018 to March 2019. Before sampling, the teat end was cleaned with 70\% ethyl alcohol with dry and the first three steams of milk were discarded. Ten ml of milk were collected in sterile test tubes under aseptic condition, then immediately transported to the laboratory on ice [20].

\section{Detection of Subclinical Mastitis}

All milk samples were subjected to CMT test by taking two ml of each sample, mixing it with an equal volume of CMT reagent (CMTR, Immucell, USA) in a plastic paddle, and shaking gently in a horizontal plane. The reactions were scored within 10-15 sec. of mixing and graded as,,++++++ for positive, trace and negative [20]. 


\section{Source of fungus isolates}

P. chrysogenum was isolated from milk samples from cows infected by mastitis (subclinical) as tested by CMT. These isolates were cultured on Sabouraud dextrose Agar (Himedia -India) containing $0.05 \mathrm{mg} / \mathrm{ml}$ of chloramphenicol. The samples were then incubated at $25 \pm 2{ }^{\circ} \mathrm{C}$ for $4-7$ days and diagnosed macroscopically and microscopically [21]. Urease production was also tested in samples cultured on Czapek Dox Agar (Oxoid -England).

\section{DNA extraction}

The pure isolates of fungus, already grown on Sabouraud Dextrose Agar at $25 \mathrm{C}$ for 7 days, were used for DNA isolation. Genomic DNA was extracted from fungal isolates according to the protocol of ZR Fungal/Yeast/Bacteria DNA mini prep Kit (Zymo/USA) following the instructions of the manufacturer. The concentration and purity of DNA were estimated by spectrophotometer at $302 \mathrm{~nm}$.

Agarose gel electrophoresis of DNA

Electrophoresis was applied to determine DNA fragments[22].

\section{Preparation of samples}

Three $\mu$ l of the processor loading buffer (Intron / Korea) was mixed with $5 \mu$ lof the DNA supposed to be used for electrophoresis (loading dye). After the mixing process, the mixture was loaded into the holes of the gel. An electrical current of 7 vlc 2 was applied for 1-2 h till the tincture reached to the other side of the gel. The gel was tested by a source of UV with $336 \mathrm{~nm}$ after putting the gel in a pool containing $3 \mu \mathrm{l}$ Red safe Nucleic acid (Intron / Korea) staining solution and $500 \mathrm{ml}$ distilled water. In addition, KAPA universal ladder kit was employed for determining the approximate size and quantity of double-stranded DNA on agarose gel.

\section{Primers design}

Molecular identification was performed using the primers designed in this study and manufactured by Integrated DNA technologies/USA). The sequences of the fungal gene primers and the amplicon size are demonstrated in Table-1.

Table 1- The sequences of the fungal gene primers and the amplicon size.

\begin{tabular}{|c|c|c|c|c|c|}
\hline $\begin{array}{c}\text { Gene } \\
\text { name }\end{array}$ & Primer & Sequence & Tm $\left({ }^{\circ} \mathbf{C}\right)$ & GC (\%) & $\begin{array}{c}\text { Product } \\
\text { size(base } \\
\text { pair) }\end{array}$ \\
\hline \multirow{2}{*}{ ITS } & Forward & $\begin{array}{c}5^{\prime} \text { - TCCGTAGGTGAACCTGCGG } \\
-3^{\prime}\end{array}$ & 60.3 & $50 \%$ & \multirow{2}{*}{650} \\
\cline { 2 - 5 } & Reverse & $\begin{array}{c}5^{\prime} \text { TCCTCCGCTTATTGATATGC- } \\
3^{\prime}\end{array}$ & 57.8 & $41 \%$ & \\
\hline
\end{tabular}

\section{Detection of gene ITS by using PCR}

Detection of ITS gene was conducted by using primers for amplification. A fragment of ITS was amplified using a forward primer (ITS1 F: 5'- TCCGTAGGTGAACCTGCGG -3') and a reverse primer (ITS4 R:5' TCCTCCGCTTATTGATATGC-3') supplied by IDT (Integrated DNA Technologies company, Canada.). The PCR amplification was performed in a total volume of $25 \mu 1$

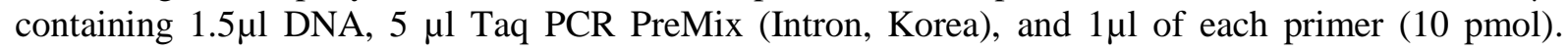
Then, distilled water was added into the tube to a total volume of $25 \mu 1$. The thermal cycling conditions were conducted as follows: Denaturation at $94{ }^{\circ} \mathrm{C}$ for $3 \mathrm{~min}, 35$ cycles of $94{ }^{\circ} \mathrm{C}$ for $45 \mathrm{~s}, 52^{\circ} \mathrm{C}$ for 1 min, and $72{ }^{\circ} \mathrm{C}$ for $1 \mathrm{~min}$, with a final incubation at $72{ }^{\circ} \mathrm{C}$ for $7 \mathrm{~min}$ using a thermal Cycler (Gene Amp, PCR system 9700; Applied Biosystem). The PCR products were separated by $1.5 \%$ agarose gel electrophoresis and visualized by exposure to ultraviolet light $(302 \mathrm{~nm})$ after red stain staining (Intron Korea ). In addition, the step of DNA gel extraction was performed according to a previously published procedure [23] by adding absolute ethanol to the wash buffer prior to initial use.

\section{Sequencing and Sequence Alignment}

The PCR products were separated on a $2 \%$ agarose gel electrophoresis and visualized by exposure to ultra violate light $(302 \mathrm{~nm})$ after Red Stain staining. Sequencing of gene was performed by the biotechnology lab, national instrumentation center for environmental management (NICEM), Korea,, using DNA sequencer 3730XL (Applied Biosystem). Homology search was conducted using Basic Local Alignment Search Tool (BLAST) program, which is available at the National Center of Biotechnology Information (NCBI), and BioEdit program. 


\section{Detection of virulence factors of Penicillium chrysogenum}

Albumin: The hydrolysis of albumin was prepared by well diffusion method [24]. Two wells were made in a proteinase production medium which contained bovine serum albumin, prepared by taking $68 \mathrm{ml}$ of a solution composed of $\mathrm{MgSo} 4.7 \mathrm{H} 2 \mathrm{O}(0.04) \mathrm{g}, \mathrm{K} 2 \mathrm{Hpo} 4(0.5) \mathrm{g}$, Nacl (1)g, yeast extract $(0.2) \mathrm{g}$, glucose (4)g and bovine serum albumin (BSA) (0.5)g [25]. The $\mathrm{pH}$ of this medium was adjusted to 4 , then the solution was sterilized by filtration using Millipore filter $(0.22) \mu \mathrm{m}$. The medium was mixed with $140 \mathrm{ml}$ of agar which was sterilized in autoclave at $121^{\circ} \mathrm{C}$ under 15 pound/inch ${ }^{2}$ for $15 \mathrm{~min}$, then poured into sterile petri dishes using sterilized cork borer $(5 \mathrm{~mm})$ with micropipette. Small parts of fungus $\left(5 \mathrm{~mm}\right.$ ) were then placed in these wells, and the petri dishes were incubated at $25^{\circ} \mathrm{C}$ for $5-7$ days. The proteolysis mold appeared as surrounded by a translucent clear zone due to the hydrolysis of albumin.

Casein: The hydrolysis of casein was prepared by well diffusion method [24]. Three wells were made in a skim milk agar medium composed of potato dextrose agar with $10 \%$ sterile skim milk added just before pouring the plates. This medium was prepared with modification of a previously reported method [26] using sterilized cork borer $(5 \mathrm{~mm})$ with micropipette and cut out of the agar. Then a small part of this fungus was placed in the wells and the petri dishes were incubated at $25^{\circ} \mathrm{C}$ for $5-7$ days. The proteolysis mold appeared as surrounded by a translucent clear zone due to the hydrolysis of casein.

Hemolytic activity: $P$. chrysogenum was grown on SDA medium supplemented with 5\% glucose and $5 \%$ sheep blood. Then, the petri dishes were incubated at $25^{\circ} \mathrm{C}$ for up to 7 days and the hemolytic activity was classified as absent, partial, or total [27].

Urease test: $P$. chrysogenum was grown in a tube containing urea agar by stabbing and incubated at $25{ }^{\circ} \mathrm{C}$ for 3-5 days. The appearance of red or pink color in the medium indicated a positive result, evidencing raised $\mathrm{PH}$ (alkalinisation) due to urea breakdown and subsequent medium color change [15].

Growth on $37^{\circ} \mathrm{C}$ : The growth assay at $37^{\circ} \mathrm{C}$ was carried out in a petri dish containing SDA medium and $P$. chrysogenum was inoculated into 2 different petri dishes, one was incubated at $25^{\circ} \mathrm{C}$ and the other at $37^{\circ} \mathrm{C}$, in order to evaluate the ability of this species to develop in above-ambient temperature [15].

\section{Results and discussion}

\section{California mastitis test (CMT)}

Out of a total of 100 samples of milk isolated from cows with mastitis (subclinical), which were examined from Abu-ghraib regions by California test, 85 (85\%) samples showed positive (+ve) results for CMT and 15 (15\%) samples confirmed negative (-ve) results (Table- 2). This result agree with that reported previously [28] and is caused by the interaction of host pathogens and environmental factors [29]. It can also be due to unhygienic conditions and prolonged treatment with the antibiotic, which may lead to increase the risk of fungal infection [30]. In addition, this study showed that sub clinical mastitis was more prevalent than clinical mastitis, which is similar to earlier results $[31,32]$.

Table 2-Results of California test

\begin{tabular}{|c|c|c|c|c|}
\hline $\begin{array}{c}\text { No. of milk } \\
\text { samples }\end{array}$ & $\begin{array}{c}\text { No. of (+ve) } \\
\text { CMT samples }\end{array}$ & $\%$ & $\begin{array}{c}\text { No. of (-ve) } \\
\text { CMT samples }\end{array}$ & $\%$ \\
\hline 100 & 85 & $85 \%$ & 15 & $15 \%$ \\
\hline
\end{tabular}

\section{Percentage of mycotic mastitis}

The results of 100 milk samples revealed that $66(66 \%)$ had mycotic mastitis isolates, of which 31 isolates belonged to Penicillium spp. (46.9\%), including 23 isolates of $P$. chrysogenum (23/66, 34.8\%) , as shown in Table- 3. Several studies indicated the isolation of penicillium spp. from bovine mastitis [33, 34, 35]. One study [36] indicated that Penicillium spp., after Candida spp., was the predominant fungi in clinical and sub clinical mastitis. No previous study suggested the isolation of $P$. chrysogenum from bovine mastitis, due to very little attention to this topic and because this fungus was used to produce a type of antibiotics (penicillin) [37]. Mastitis remains an unsolved problem because of its 
complex etiology [3]. Bovine mycotic mastitis was reported to be responsible for 1-13\% of all mastitis cases [1]. The present study is considered the first to isolate this fungus from bovine mastitis in Iraq.

Table 3- Prevalence of mycotic infection in subclinical mastitis.....

\begin{tabular}{|c|c|c|c|c|c|c|}
\hline $\begin{array}{c}\text { No. of } \\
\text { milk } \\
\text { samples }\end{array}$ & $\begin{array}{c}\text { No. of } \\
\text { mycotic } \\
\text { isolates }\end{array}$ & $\%$ & $\begin{array}{c}\text { No. of } \\
\text { Penicillium } \\
\text { spp. }\end{array}$ & $\%$ & $\begin{array}{c}\text { No. of } \\
\text { Penicillium } \\
\text { chrysogenum }\end{array}$ & $\begin{array}{c}\text { \%of } \\
\text { Penicillium } \\
\text { chrysogenum } \\
\text { to mycotic } \\
\text { isolates }\end{array}$ \\
\hline 100 & 66 & $66 \%$ & 31 & $46.9 \%$ & 23 & 34.8 \\
\hline
\end{tabular}

\section{Identification of Penicillium chrysogenum}

Penicillium chrysogenum was isolated and identified by subculture on SDA and incubation at $25^{\circ} \mathrm{C}$ for 5-7days. The colonies appeared green or pale green-blue, changing to darker green with white margins, with velvety in texture. Exudate droplets were present in the center of colonies, having pale yellow to bright yellow color, as shown in Figure- (1-A), while this exudate was occasionally absent, as shown in Figure- (1-B). Also, the color of colonies sometimes appeared as white in color, as in Figure- (1-C), or changing to red or pink, as in Figure- (1-D). This is because many of Penicillium genera lose all of their green color with age, leading to various shades of yellowish brown and reddish brown to almost fuscous. The color of the colonies of the same species differs on different media [38].
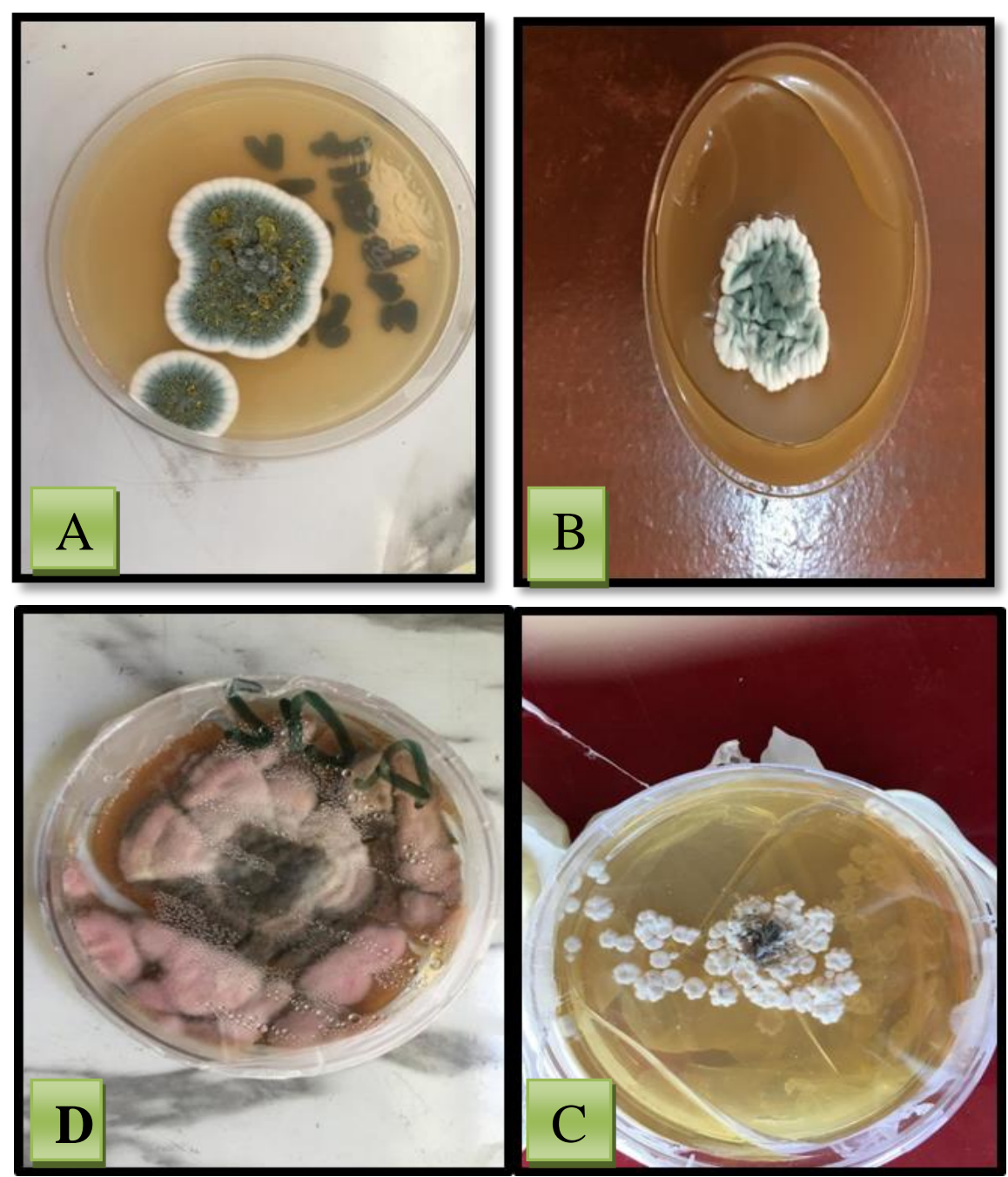

A- Figure 1- Macroscopically appearance of $P$. chrysogenum on SDA at $25^{\circ} \mathrm{C}$ for 7 days; A- Exudate, B- Without exudate, C- White color colonies, and D- Red color colonies 
The growth of this fungus was rapid on Czapek Doxes Agar and the color of colonies appeared pale green. The exudate was limited or absent, as in Figure- (2-A), with yellow pigment on the reverse side of the petri dish, as in Figure- (2-B).

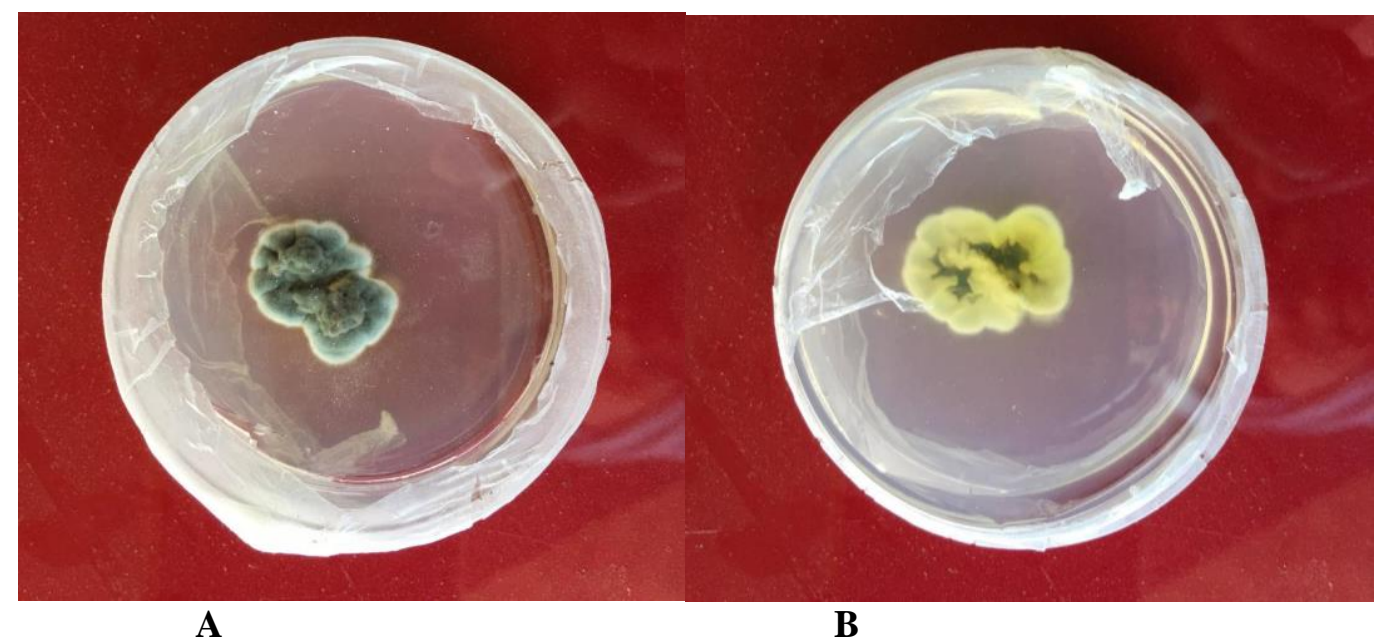

Figure 2- Macroscopically appearance of $P$. chrysogenum on Czapek Doxes Agar (A), and the reverse side of Czapek Doxes Agar showing yellow pigment (B).

The microscopic examination of $P$. chrysogenum was performed by taking a small part of fungal growth and mixing it with one drop of lactophenol cotton blue stain. The specimen was covered with a cover slide and examined under microscope with 40x lens. This fungus appeared similar to the other Penicillium spp., showing a brush-like arrangement with septate hyaline hyphae. The conidia appeared subglobose to ellipsoidal with 2-3 stages of strigmata borne on the conidiophores, as shown in Figure3.

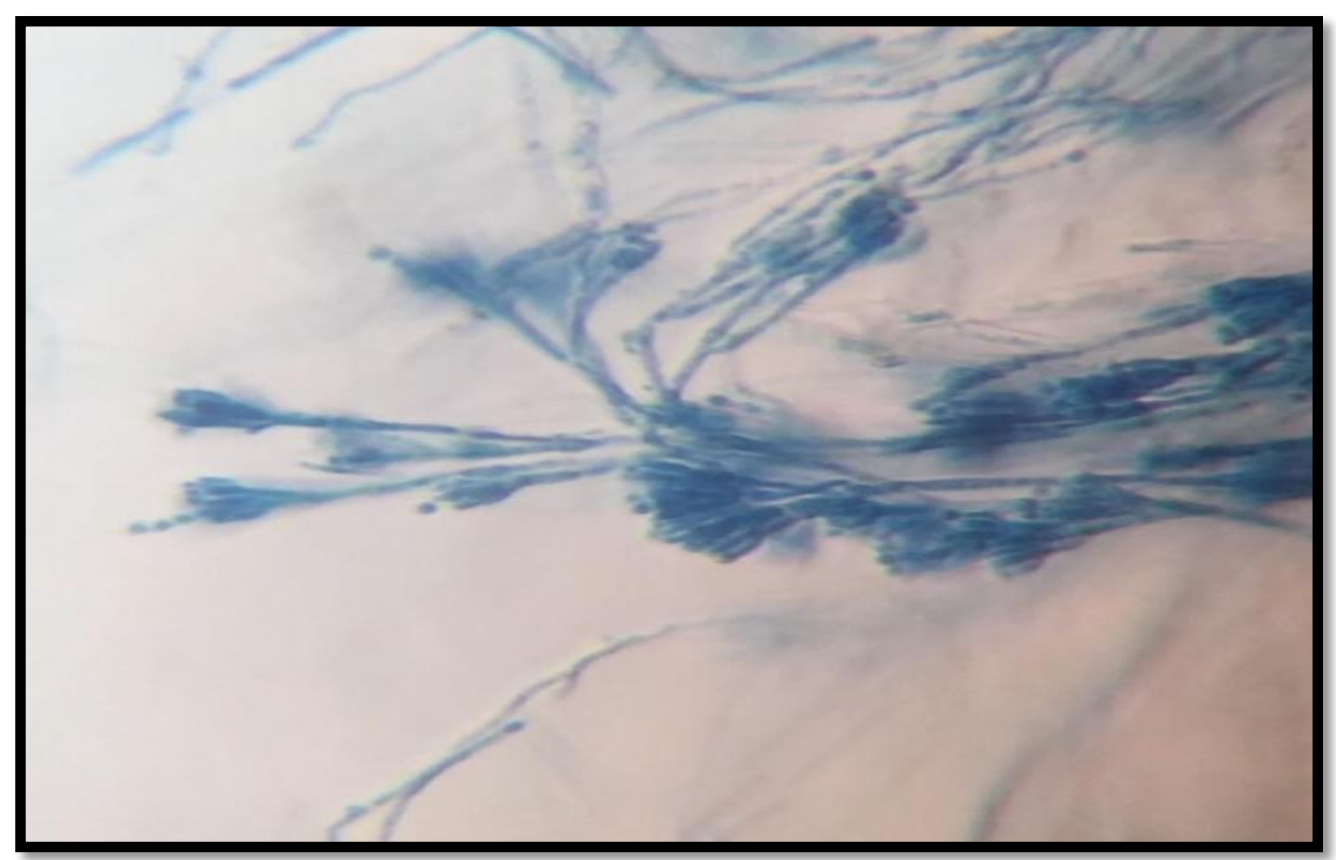

Figure 3-Microscopic appearance of $P$. chrysogenum by using lactophenol cotton blue stain (40X) 
The macroscopic and microscopic features of $P$. chrysogenum were similar to the description provided by previous works $[39,40]$. Also $P$. chrysogenum was different from $P$. marneffe $i$ which is considered as a dimorphic fungus with the ability to especially infect humans and bamboo rats.

\section{Molecular identification}

Penicillium chrysogenum was identified based on the morphological characteristic as well as the genetic analysis of their ITS1, ITS2, 5.8S and 28S regions of rDNA. The results of the genetic identities showed that the isolate of $P$. chrysogenum had $94 \%$ matching with the reference strain. This strain of P. chrysogenum was found to be XQ23 with a sequences accession number of Ku216725.1. The amplification of ITS region was successful for this isolate and yielded a PCR band of approximately 650 base pair (bp) in gel electrophoresis, as shown in Figure- 4.

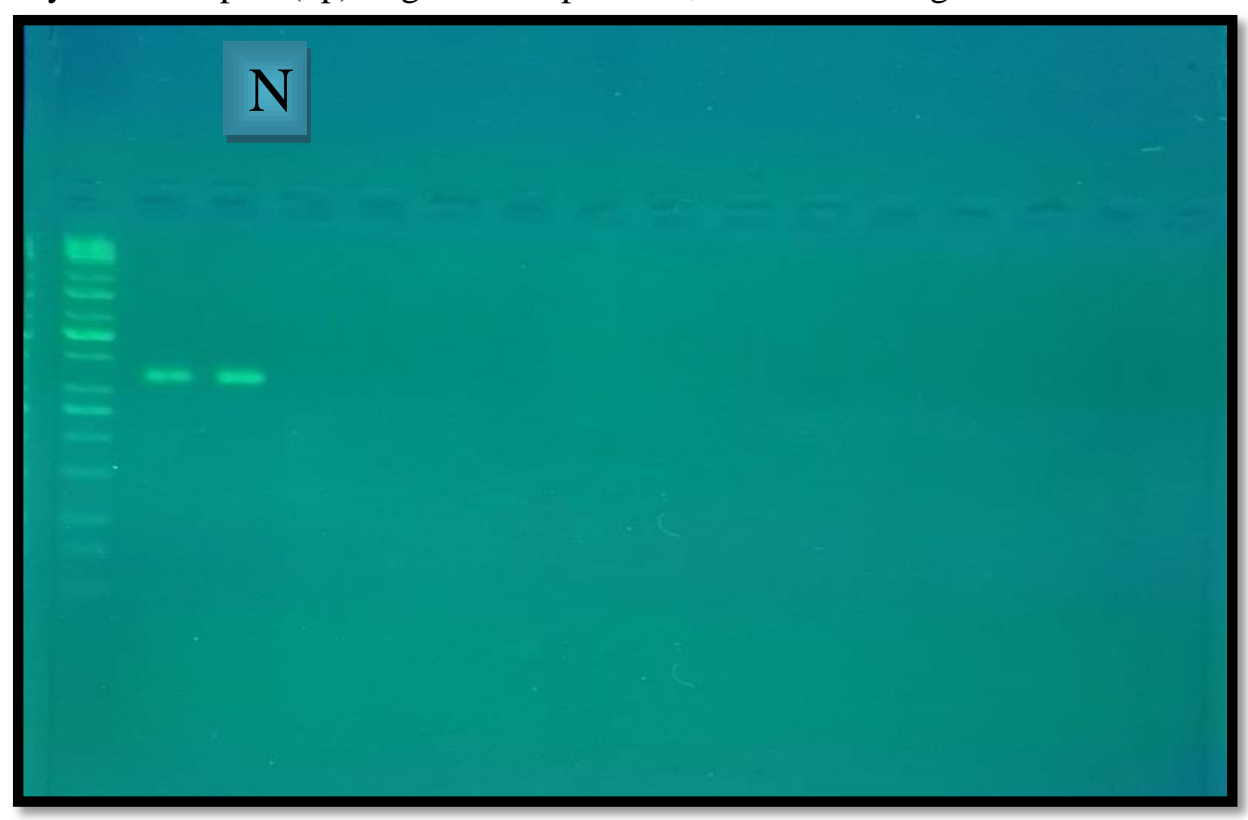

Figure 4- Gel electrophoresis on $2 \%$ agarose at 5 volt $/ \mathrm{cm}^{2}$ showing PCR product of $P$. chrysogenum at the band size $650 \mathrm{bp}$. for 1:30 hours. N: DNA ladder

\section{Virulence factors of $P$. chrysogenum}

Virulence factors are properties which increase the survival, growth, and propagation of fungi in animal tissues [41]. From a total of 23 samples of $P$. chrysogenum isolated from 100 samples of milk, several virulence factors were evaluated and the results showed that all the isolates were able to degrade both proteins (albumin and casein) but in different degrees of virulence (higher, moderate and low). The inhibition zones of higher degrees of virulence for albumin and casein were 35 and $26 \mathrm{~mm}$, respectively, shown in $4.34 \%$ and $13.04 \%$ of the isolates 1 and 3 , respectively. Whereas, the inhibition zones of lower degrees of virulence for albumin and casein were 15 and $18.3 \mathrm{~mm}$, respectively, shown in $(13.04 \%$ and $8.69 \%$ of the isolates 3 and 2, respectively. The results are shown in Tables- 4 and 5 and Figures- 5 and 6, respectively. These results are in agreement with those of a previous study [15] which stated the ability of $P$. chrysogenum isolated from poultry barns to hydrolyse albumin and casein because this fungus contains hemolytic enzymes (proteinase enzymes). Another article [42] suggested that microbial cells secrete hydrolytic enzymes which destroy the constituents of host cell membranes, leading to membrane dysfunction and physical disruption, as well as the aid in the invasion of host tissues.

Table 4-The results of measurement of diameter of inhibition zone of albumin

\begin{tabular}{|c|c|c|c|}
\hline Degree of virulence & No. of isolates & Percentage (\%) & $\begin{array}{c}\text { Diameter of } \\
\text { inhibition zone (mm) }\end{array}$ \\
\hline Higher & 1 & 4.34 & 35 \\
\hline Moderate & 3 & 13.04 & 20 \\
\hline Low & 3 & 13.04 & 15 \\
\hline Very low & 16 & 69.56 & $5-10$ \\
\hline
\end{tabular}


Table 5-The results of measurement of diameter of inhibition zone of casein

\begin{tabular}{|c|c|c|c|}
\hline Degree of virulence & No. of isolates & Percentage (\%) & $\begin{array}{c}\text { Diameter of } \\
\text { inhibition zone (mm) }\end{array}$ \\
\hline Higher & 3 & 13.04 & 26 \\
\hline Moderate & 4 & 17.39 & 25 \\
\hline Low & 2 & 8.69 & 18.3 \\
\hline Very low & 14 & 60.86 & 10 \\
\hline
\end{tabular}

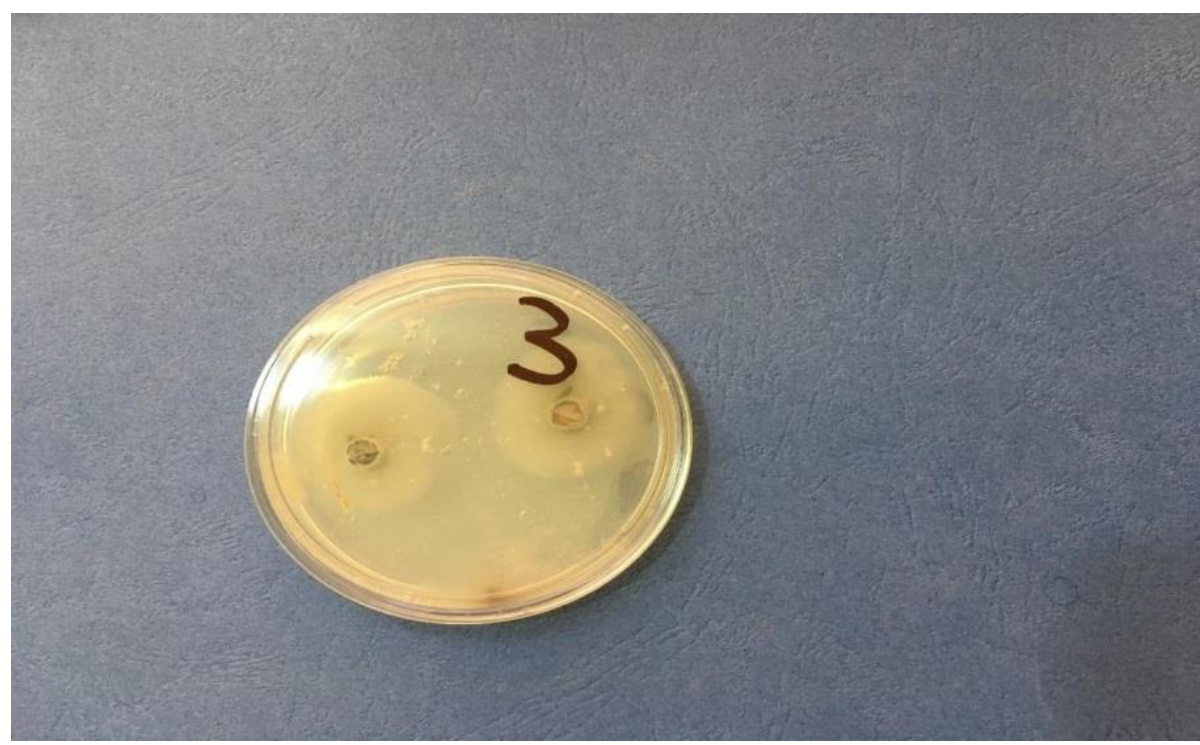

Figure 5-Hydrolysis of albumin by $P$. chrysogenumon proteinase production in the medium

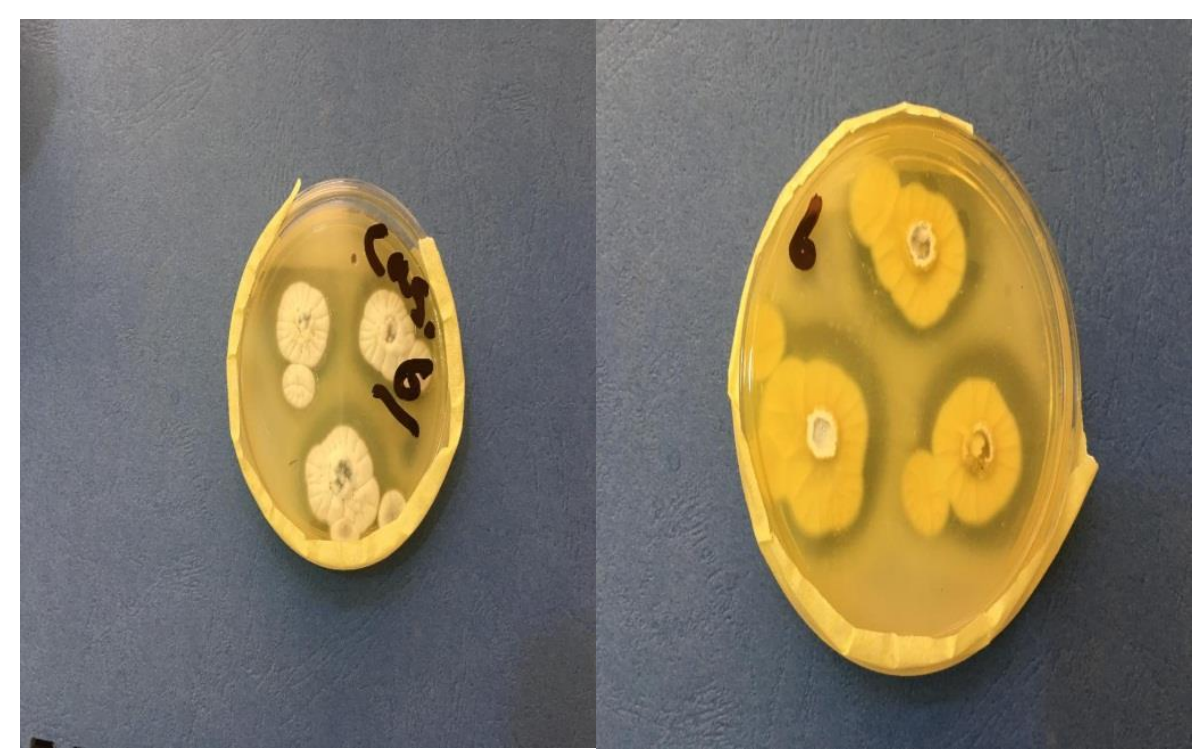

Figure 6-Hydrolysis of casein by P. chrysogenum on Skim Milk Agar

In addition, this fungus was able to hydrolyse urea and change the color from yellow-orange to pink. A total of 10 isolates $(43.47 \%)$ of this fungus changed the color to dark pink, which indicates a higher degree of virulence. While, 5 isolates $(21.73 \%)$ did not change color as shown in Figure-7 and Table-6. This result is in agreement with that of a previous study [15] which reported that $P$. chrysogenum was able to hydrolyse urea and has the capacity to hydrolyse urea, which is recognized as an important factor for pathogenicity of fungi. 


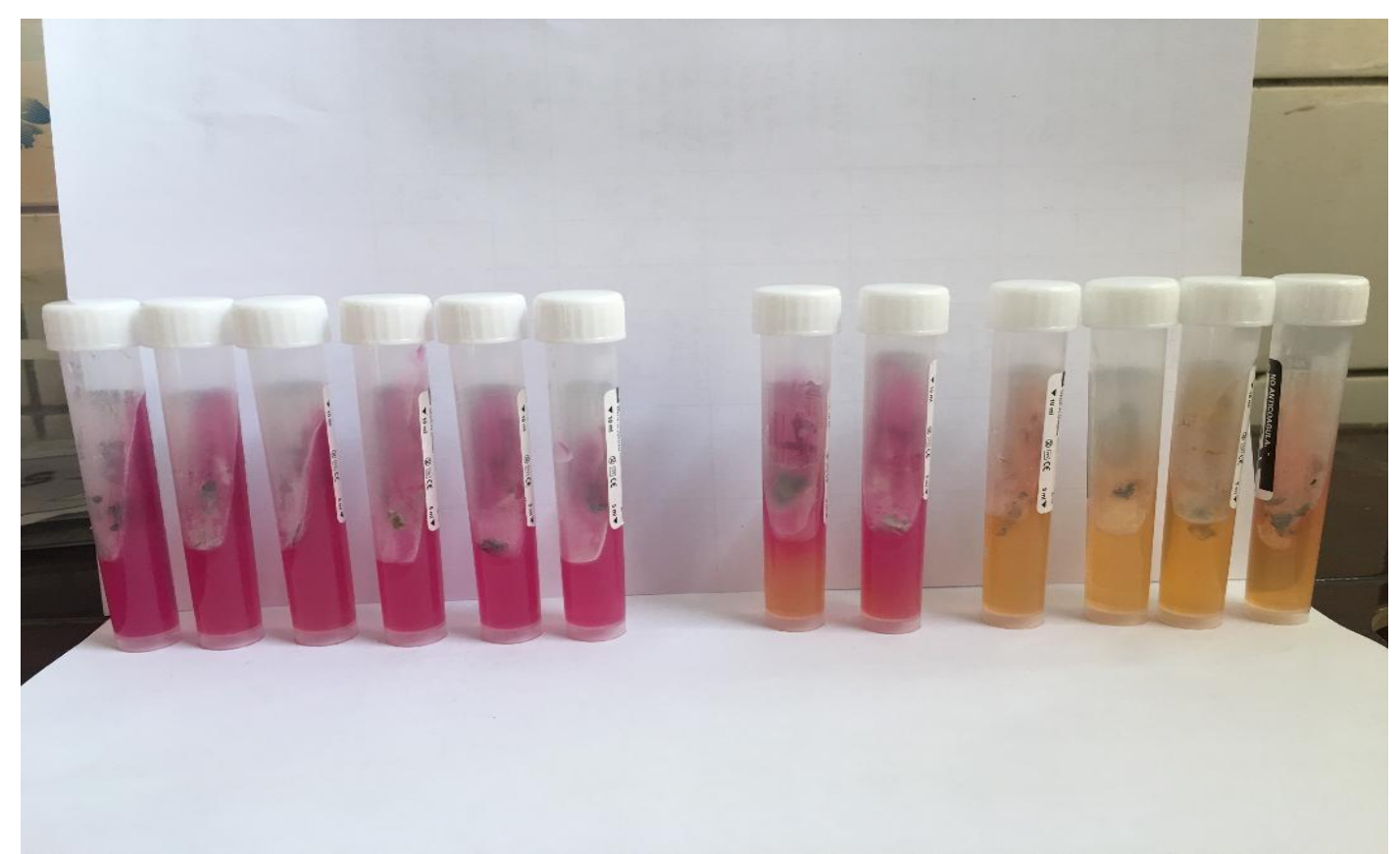

Figure 7- Hydrolysis of urea by P. chrysogenum on Urea Agar

Table 6-The results of growth of the isolates of $P$. chrysogenum on urea agar

\begin{tabular}{|c|c|c|c|}
\hline Degree of virulence & No. of isolates & Percentage (\%) & Color \\
\hline Higher & 10 & 43.47 & Dark pink \\
\hline Moderate & 8 & 34.78 & Light pink \\
\hline No changing color & 5 & 21.73 & Orange-yellow \\
\hline
\end{tabular}

On the other hand, this fungus was able to grow on $25^{\circ} \mathrm{C}$ and $37^{\circ} \mathrm{C}$, as shown in Figure-8. This result is highly similar to that of earlier works [15, 18, 43, 44] [44], which reported that $P$. chrysogenum can grow at $37 \mathrm{C}$ despite their isolation from a very cold habitat, indicating that the fungus was thermotolerant. Thermo-tolerance is a crucial virulence factor for establishing the invasive type of infection in humans and animals, which is a trait that is lacking in most fungi. The other result of virulence factors of P. chrysogenum was the observation of no hemolytic activity on Blood Agar, as shown in Figure-9. This result is highly similar to that previously reported [15], but inconsistent with another study [45]. This inconsistence is possibly due to environmental conditions, source of isolate, and the method used in the detection of the hemolysin enzyme that may be produced from some Penicillium spp genera. However, another article [44] indicated that $P$. chrysogenum exhibited some degree of hemolysis on blood agar, only when incubated at $37^{\circ} \mathrm{C}$, as well as all the virulence factors, as illustrated in Table-7.

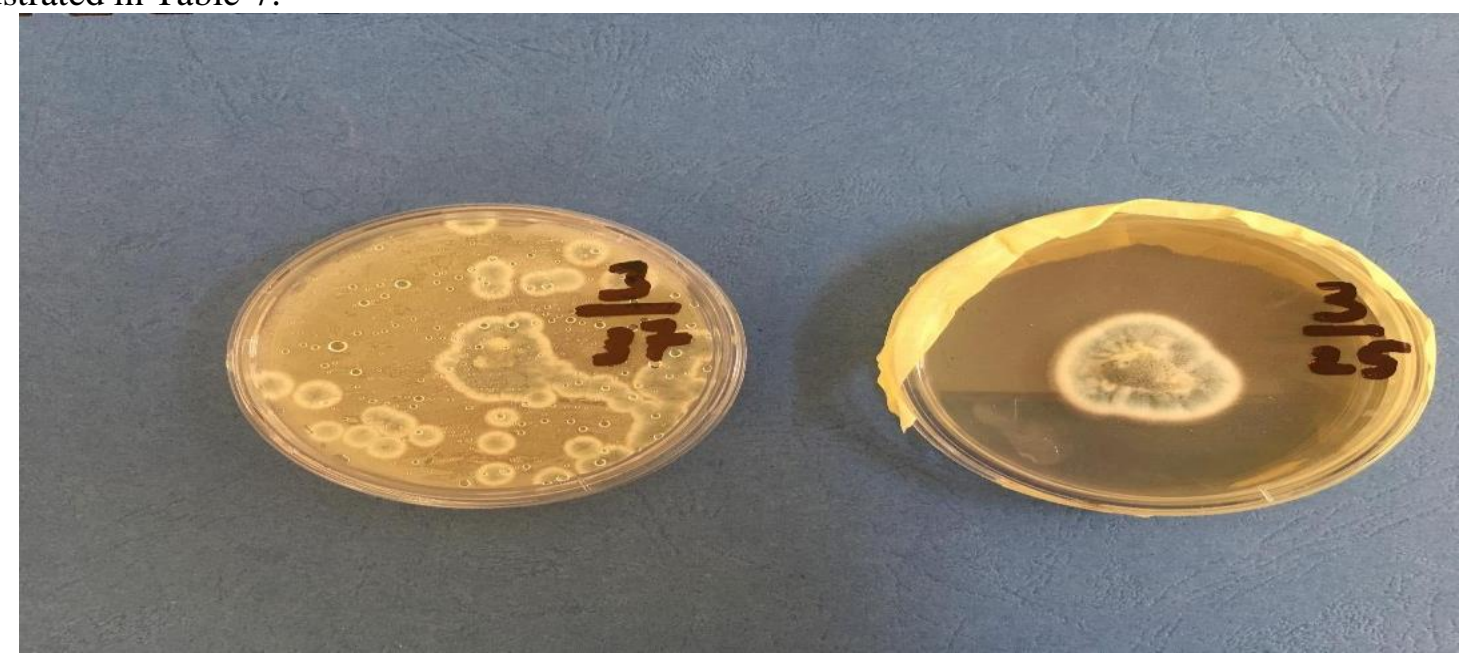

Figure 8- $P$. chrysogenum growth on $25^{\circ} \mathrm{C}$ and $37 \mathrm{C}$ for 7 days 


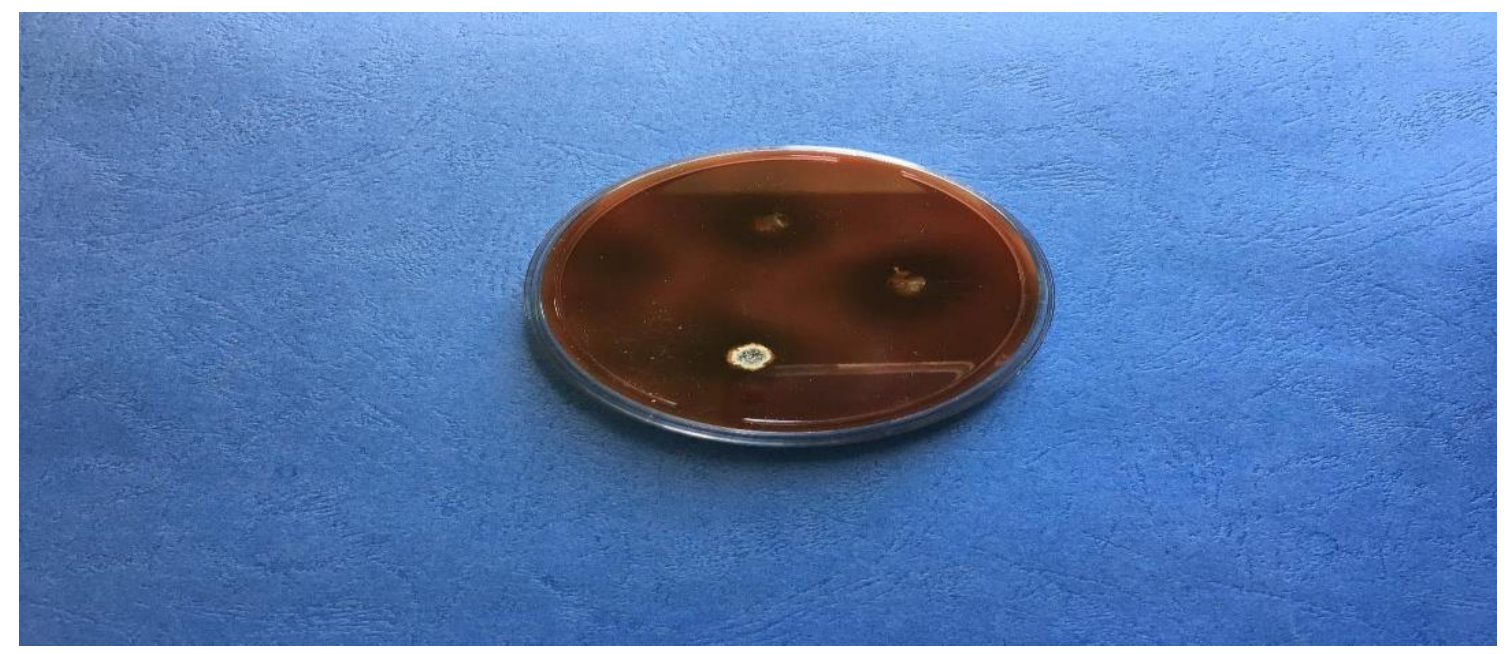

Figure 9-P. chrysogenum with no hemolytic activity on Blood Agar

Table 7- The results of virulence factors of Penicillium chrysogenum

\begin{tabular}{|c|c|c|c|c|c|}
\hline Fungus & Albumin & Casein & Hemolysis & Urease & Grow on 37C \\
\hline $\begin{array}{c}\text { Penicillium } \\
\text { chrysogenum }\end{array}$ & Positive & Positive & $\begin{array}{c}\text { Absence of } \\
\text { activity }\end{array}$ & Positive & Positive \\
\hline
\end{tabular}

\section{Conclusions}

Mycotic mastitis, especially sub clinical mastitis, which occurs through fungal infection is a major problem due to the absence of signs of inflammation or milk abnormalities, causing economic losses and reduced milk production. This study highlighted that $P$. chrysogenum may cause bovine mastitis by the production of many types of virulence factors which are very important in pathogenicity of this fungus. This study is considered the first report about the isolation of $P$. chrysogenum from bovine mastitis in Iraq, revealing 34.8\% cases of mycotic bovine mastitis. Hence, further studies are needed to investigate the other types of virulence factors and other types of Penicillium spp. which can be isolated from clinical and/or sub clinical isolates of bovine mastitis

\section{References}

1. Nadhom, B. N.2018. Study of molecular composition of virulence bacteria isolated from bovine mastitis with biofilm production. Iraqi J. of Agri. Sci. 49(5):840-846.

2. Kalińska, A.; Gołębiewski, M. and Wójcik, A.2017. Mastitis pathogens in dairy cattle - a review. World scientific news. 89: 22-31.

3. Abd El-Razik, K. A.; Abdelrahman, K. A.; Abd El-Moez, S.I.and Dania, E. N.2011. New approach in diagnosis and treatment of Bovine Mycotic mastitis in Egypt. J. African of Microbiology Research. 5(31):5725-5732.

4. Dubiea, T.; Sisayb, T.; Gebrua,M.andMuktar, Y.2015. An Insight Review on the Role of Fungi in Mastitis of Dairy Animals and Its Economical Importance. J. of Veterinary Science. Photon. 116: $440-445$.

5. Krukowski, H.and Saba, L.2003. Bovine mycotic mastitis, Department of Animal and Environmental Hygiene University of Agriculture in Lublin, Str. Akademicka 13,20-950Lublin Poland Folia Veterinaria. 47(1): 3-7.

6. Yassein, S. N.2020. Comperative study of pathogenicity between Aspergillus fumigatus and Penicillium chrysogenum in mice. Iraqi J. of Agricultural Sciences (Special Issue).51:168-175.

7. Houbraken, J. and Samson, R. A. 2011. Phylogeny of Penicillium and the segregation of Trichocomaceae intro three families. Stud. Mycol.70:1-51.

8. Oleksandr, S.2016. Secondary metabolism by industrially improved Penicillium chrysogenum strains .Oleksandr Salo; Roel, A. L.and Bovenberg Arnold, J. M. Driessen. Secondary metabolite production by Penicillium chrysogenum(chapter1).university of Groningen.

9. Böhma, J.;Hoffa, B.;O’Gormana, C. M.; Wolfersa, S.;Klixc, V.; Bingera, D.; Zadrad, I.; Kürnsteinerd , H.; Pöggelerc , S.; Dyerb, P. S. and Kücka, K.2013.Sexual reproduction and 
mating-type-mediated strain development in the penicillin-producing fungus Penicillium chrysogenum. PNAS. 110(4):1476-1481.

10. Avile' s -Robles, M.; Go' mez-Ponce, C.; Rese'ndiz-Sa'nchez, J. Rodri'guez-Tovar, A. V.; Ceballos-Bocanegra,A.and Mart1'nez-Rivera,A.2016.Disseminated penicilliosis due to Penicillium chrysogenum in a pediatric patient with Henoch-Scho" nlein syndrome.International J. of Infectious Diseases. 51: 78-80.

11. Guzmán-Chávez, F.; Zwahlen, R. D.; Bovenberg, R. A. L. and Driessen, A. J. M.2018. Engineering of the filamentous fungus Penicillium chrysogenum as Cell Factory for Natural Products. Front. Microbiol. 9:2768.

12. Kourkoumpetis, T.K.; Fuchs, B.B.; Coleman, J.J.; Desalermos, A. and Mylonakis, E. 2012. Polymerase Chain Reaction-Based Assays for the Diagnosis of Invasive Fungal Infections (Review article). Clinical Infectious Diseases; 54(9):1322-1331.

13. Demirel, R.; Sariozlu, N.Y. and Ilhan, S. 2013. Polymerase chain reaction (PCR) identification of terverticillate Penicillium species isolated from agricultural soils in Eski, sehir Province. Braz Arch Biol Technol.; 56(6):980-984.

14. Mahmoud, M.A.; Abd-El-Aziz, A.R.M. and Al-Othman, M.R.2016. Molecular and biochemical taxonomic tools for the identification and classification of plant pathogenic Penicillium species. $J$. Biotechnology \& Biotechnological Equipment. 30(6): 1090-1096.

15. TiarZa, C. L.; Marcondes, N. R.; Mota, V. A. and Svidzinski, T. I. E.2011. Virulence potential of filamentous fungi isolated from poultry barns in Cascavel, Paraná, Brazil. Brazilian Journal of Pharmaceutical Sciences. 47(1):156-160.

16. UL-Haq, I.; Mukhtar, H. and Umber, H.2006.Production of Protease by Penicillium chrysogenum through optimization of environmental conditions. J. Agri. Soc. Sci. 2(1):23-25.

17. Nagamani, B.; Lakshmi, C. M. V. V.; Sridevi, V. and Rajani, P.2012. Production of Protease from Sesame Oil Cake by Penicillium Chrysogenum under Solid State Fermentation. International J. of Chemical Environmental and Pharmaceutical Research. 3(2): 137-141.

18. Borrego, S.; Molina, A.and Santana, A.2015. Mold on Stored Photographs and Maps: A Case Study. Topics in Photographic Preservation. 16:109-120.

19. Mekaprateep, M.;Chongkae, S. and Vanittanakom, N.2018. Direct and synergistic hemolytic reactions triggered by indoor airborne mold. Chiang Mai Medical J. 57(3):143-150.

20. Coles, E.H.1986.Veterinary Clinical Pathology, 4th Ed. P: 345. W.B. Saunders Company, London.

21. Baron, E.J.and Finegold, S. M.1990.Bailey and Scott's Diagnostic Microbiology. 8th Ed. Mosby Co. pp. 172-173.

22. Sambrook, J.; Fritsch, E.F. and Maniatis, T. 1989. Gel electrophoresis of DNA. In: Molecular cloning a laboratory manual, 2nd edition, Cold Spring Harbor Laboratory Press, New York, pp. 6.3-6.17.

23. Vogelstein, B. et al.1979.Preparative and Analytical Purification of DNA from Agarose Proc. Natl. J. Acad. Sci. USA, 76(2): 615-619.

24. Mahmoud, M.J.; Jawad, A. L. M.; Hussain, A. M.; Al-Omari, M. and Al-Naib, A.1989. In vitro antimicrobial activity of Salsola rosmarinus and Adiantum capillus- veneris .International J. of Crude Drug Research. 27(1): 14-16.

25. D`Eça Júnior, A.; Silva, A. F.; Rosa, F. C.; Monteiro, S. G.; Figueiredo, P. D. M. S. and Monteiro, C. D. A.2011.In vitro differential activity of phospholipases and acid proteinases of clinical isolates of Candida. Revistada Sociedade Brasileirade Medicina Tropical. 44(3):334-338.

26. Joy, J.M.;Loessner, M.J.and Golden, D. A.2005.Modern food microbiology, 7th ed., Aspen pub. Gathersburg MD.USA. pp.147-149.

27. Bonasseli,L. A.; Bertoli, M.and Svidzinski,T. I. E.2005.High frequency ofCandida parapsilosison hands of healthy host. J. Hosp. Infect.59:159-162.

28. Mohammed, S. J. and Yassein, S. N.2020. Characterization of some virulence factors of Candida albicansIsolated from subclinical bovine mastitis. Plant Archives. 20(1): 238-242

29. Rofaida, ME.2010. Isolation and identification of the bacteria associated with bovine mastitis and detection of their specific antibodies in milk and sera (Doctoral dissertation, MSc thesis, Dep. of Micro., Fac. of Vet. Med., U of K, Sudan). 
30. Pachauri, S.; Varshney, P.; Dash, SK. and Gupta, MK.2013. Involvement of fungal species in bovine mastitis in and around Mathura, India. Vet. World. 6: 393-395.

31. Abera, M.; Elias, B.; Aragaw, K.; Denberga, Y.; Amenu, K. and Sheferaw, D.2012. Major causes of mastitis and associated risk factors in smallholder dairy cows in Shashemene, southern Ethiopia.J. African of Agricultural Research. 7(24):3513-3518.

32. AL-Taee, H. S. R.; Al-Samarraae, I. A. A. and AL-Ahmed, H. I. 2019.Antibiotic Susceptibility and Molecular Detection of Pseudomonas aeruginosa isolated from Bovine Mastitis. Iraqi J. of Vet. Med. 43(2): $77-85$.

33. Sukumar, K. and James, P.C.2012.Incidence of Fungal Mastitis in Cattle. Tamilnadu J. Veterinary and Animal Sciences. 8(6): 356 - 359.

34. Al-Ameed, A. I.2013. Isolation and identification of fungal from infected milk samples obtained from cattles with mastitis and studying the antifungal activity of rosemary ethanolic extract against the main strains. J. Diyala Agricultural Sciences. 5(2): $1-13$.

35. Yanuartono; Nururrozi, A.; Indarjulianto, S.; Raharjo, S.; Purnamaningsih, H. and Haribowo, D. N.2019. Review: mastitis mikotik pada ruminansia Review: mycotic mastitis in ruminants. $J$. Ilmu-Ilmu Peternakan. 29(2): 109 - 130.

36. Al-Haddadi, W.; Elshafie, A.; Al-Ansari, A.; Al-Mawly, J.; Al-Hatali, R.; Al-Habsi, H.; andet $a l .2020$. Bovine mastitis in Oman is mainly associated with environmental bacteria that show high resistance to commonly used antibiotics. Archives of Microbiology \& Immunology. 4 (2): 38-50.

37. Lewis, J. A. and Anderson, N.2018.Penicilliumantibiotic effect. The American Biology Teacher. 80(7): 530-535

38. Refai, M.; Abo El-Yazid, H.and Tawakkol, W.2015.Monograph On The genus Penicillium(A guide for historical, classification and identification Penicillium of, their industrial applications and detrimental effects).

39. Tiwari, KL.; Jadhav, SK. and Kumar, K.2011. Morphological and molecular study of different Penicilliumspecies. Middle-East J. Sci. Res. 7(2): 210-230.

40. Gonu, H.; Opoku, N.; Appiah-Opong, R.; Oppong, K.G.; Asirifi, I. andet al.2015. Morphological characteristics of some microfungal species solated from spontaneously fermented Jatropha curcas seed meal. Elixir Microbiology \& Fermentation. 85: 34286-34290.

41. De Hoog, S.; Guarro, J.; Gene, J. and Figueras, M. J.2001.Atlas of clinical fungi. 2. ed. Réus: ASM Press, p.1126.

42. Salyers, A. and Witt, D.1994.Virulence factors that damage the host. Bacterial pathogenesis: a molecular approach. ASM Press, Washington, D.C, pp. 47-62.

43. Guevara-Suarez, M.; Sutton, D. A.; Cano-Lira, G. F.; García, D.; Martin-Vicente, A.; Wiederhold, N.; Guarro, J. andet al.2016. Identification and Antifungal Susceptibility of Penicillium-Like Fungi from Clinical Samples in the United States .J. Clinical Microbiology. 54(8): 2155-2161.

44. Perini, L.; Mogrovejo, D. C.; Tomazin, R.; Car, C. G.; Brill, F. H. H. and Gunde-Cimerman, N.2019. Phenotypes Associated with Pathogenicity: Their Expression in Arctic Fungal Isolates, Microorganisms .7(600):1-15.

45. Mezher, M. A.; Raoof, W. M. and Bandar, K.I. 2015. Identification study some virulence factors of invasive mold infections isolated from patients undergoing chemotherapy in Tikrit teaching Hospital. Egypt. Acad. J. Biology. Sci. 7(1): 1 - 11. 